Article

\title{
Sustainability Initiatives in Emerging Economies: A Socio-Cultural Perspective
}

\author{
Mohsin Malik ${ }^{1, *}$ and Salam Abdallah ${ }^{2}$ \\ 1 Department of Business Technology and Entrepreneurship, Swinburne Business School, Swinburne \\ University of Technology, Hawthorn 3122, Australia \\ 2 College of Business Administration, Abu Dhabi University, Abu Dhabi, UAE \\ * Correspondence: mmalik@swin.edu.au
}

Received: 1 August 2019; Accepted: 3 September 2019; Published: 6 September 2019

\begin{abstract}
This paper explains how and why sustainable supply chain management (SSCM) is different in an emerging economy by investigating sustainability initiatives in the United Arab Emirates. This exploratory qualitative study uses activity theory (AT) as a framework of analyses to investigate the sustainable supply chain practices in the context of emerging economies. AT's hierarchical breakdown structure allows complex and dynamic activities to be broken down across multiple levels providing a simplified explanation of the triple bottom line initiatives across 16 participant organizations. Our findings corroborate with some of the sustainability initiatives in developed countries, such as the contribution of suppliers and the importance of employee engagement to the sustainable efforts of the focal firm; however, there were significant differences too. Customer and investor pressure was the top driver toward sustainability in developed economies, but our research identifies government pressure as the principal motive for sustainability. Similarly, we observe a narrow perspective on sustainability from the studied organizations as sustainability measures were seen as "costly". We attribute this to a lack of accounting for the costs associated with being "unsustainable". We contribute to the literature by developing four propositions that identify the key contributors to successful sustainability outcomes in the context of emerging economies: (a) the dynamic influence of governments on the adoption and implementation of SSCM; (b) accounting for the costs associated with the "unsustainable" measures, which enables a strategic perspective on sustainability; (c) the inclusion of sustainability as an "order qualifier" for the suppliers; and (d) the employees' transition from compliance to taking ownership of sustainability initiatives.
\end{abstract}

Keywords: sustainable supply chain management; activity theory; emerging economies

\section{Introduction}

Sustainability is currently a business imperative because stakeholders increasingly expect organizations to conduct their operations in a socially and environmentally responsible manner. The rapid consumption of resources, driving the current economic development and offshoring of manufacturing facilities, broadened the focus of sustainability to include both the upstream and downstream operations of supply chains [1]. Globalization and offshoring transcend geographical boundaries, which also brings with itself sustainability challenges along the upstream operations of global supply chains. The inhumane working conditions at the first- or second-tier suppliers, which led to the Bangladesh's Rana plaza building collapse, exposed the varying degree of sustainability implementation in supply chains [2]. The garment factories housed at the now infamous Rana plaza were supplying to leading Western brands and retailers, showing that the working standards and conditions along the supply chains were variable. When not required, the companies based in developed economies tend to be less socially responsible in the developing world mainly because of different 
contextual settings. Walker and Jones [3] observed that the approach of businesses to sustainability is contingent on the context and the external pressures exerted by stakeholders, which may vary across industrial segments. Silvestre [4] extended the contextual differences to the geographical boundaries that resulted in different types and intensities of stakeholder pressure. The contextual differences between emerging and developed economies are also underpinned by both the sophistication and enforcement of the sustainability regulations [5]. Furthermore, the sustainable production and consumption patterns in emerging countries are also strongly influenced by the institutional settings and the social demography. For example, developing countries' sustainability efforts are hampered by lower literacy levels, lower-skilled workforces, inadequate physical infrastructure, inconsistent law enforcement, and inadequate/nonexistent financial services [1]. This leads us to the background of this study that the sustainability initiatives are context-specific which involve stakeholders and social interactions at various levels.

We respond to the call by literature [5] to identify trends and different pathways to achieve sustainability in multiple emerging countries. We contribute to the literature by conceptually theorizing the interactions between individuals and organizations at the individual, group, and institutional levels. We are particularly interested in determining if the institutional-level interactions can be mediated to improve the sustainable performance of supply chains in the particular context of emerging economies. We chose the practice-based activity theory (AT) as the framework of analysis to support our research premise that the transition to sustainability is dynamic, social, and context-specific. AT analyzes human activity systems by contextualizing the mediated and dialectic relationships as individuals work toward a shared goal [6,7]. More specifically, this study employs a qualitative research design involving 16 organizations to investigate the following research question: "How and why sustainable supply chain management (SSCM) initiatives may vary in emerging economies".

To achieve this, Section 2 reviews the literature on SSCM in the context of emerging economies, and the relevance and suitability of the AT analyses to the research question are also established. Section 3 explains the methodology by providing an illustration of AT constructions for the SSCM initiatives for three participant organizations. Section 4 describes the research findings from the 16 participant organizations. The discussion on the research findings is carried out in Section 5, which leads to the development of four research propositions. The study is concluded in Section 6, where the limitations of the current research are discussed, and future research directions are identified.

\section{Literature Review}

\subsection{Sustainable Supply Chain Management (SSCM) for Emerging Economies}

SSCM reflects the principle that an organization's sustainability impact must be considered along its entire supply chain. The extant SSCM literature focused strongly on environmental sustainability issues such as environmentally friendly processes and resource conservation [1]. The more nuanced sustainability topics relating to the social interactions in the supply chains, such as community engagement and exploiting human capital [8], received less attention. To determine the status of the extant SSCM literature, a review was firstly conducted to identify the actors, as well as their motivations, actions, and practices in SSCM initiatives. The summary of the findings of this review is shown in Table 1. 
Table 1. Summary of the sustainable supply chain management literature.

\begin{tabular}{|c|c|c|c|}
\hline \multicolumn{4}{|c|}{ Sustainable Supply Chain Management (SSCM) } \\
\hline \multicolumn{2}{|c|}{ Who-The Transformational Actors } & \multicolumn{2}{|l|}{ Why-The Motives } \\
\hline \multicolumn{2}{|c|}{ Organizational Actors } & \multicolumn{2}{|l|}{ Stakeholder Pressures } \\
\hline Senior management & {$[9,11]$} & Governmental policy and vision & [18] \\
\hline Supply chain/procurement & [19] & Regulations compliance & {$[13,20,21]$} \\
\hline Employees & [9] & Customers & [22] \\
\hline \multicolumn{2}{|c|}{ Supply Chain Actors } & Investors and shareholders & {$[9]$} \\
\hline Suppliers & {$[10,23]$} & Media & [3] \\
\hline Customers & [24] & NGOs and community groups & [11] \\
\hline \multicolumn{2}{|c|}{ Community Actors } & \multicolumn{2}{|l|}{ Strategic Decisions } \\
\hline Government and regulatory & [9] & Corporate social responsibility (CSR) & [25] \\
\hline authorities & [24] & Competitive pressures & [10] \\
\hline Certification and auditing bodies & & Reputational risk avoidance & [26] \\
\hline \multicolumn{4}{|c|}{ How-The Actions and Practices } \\
\hline \multicolumn{2}{|c|}{ Internal Environmentally Friendly Practices } & \multicolumn{2}{|c|}{ External Environmentally Friendly Practices } \\
\hline 1-4 Green product design & [27] & Environmentally friendly sourcing & {$[19,28]$} \\
\hline Green manufacturing & [29] & Auditing suppliers & [30] \\
\hline Green logistics & [31] & Supplier collaboration & [12] \\
\hline Reverse logistics & [32] & $\begin{array}{l}\text { Environmental collaboration with } \\
\text { customers }\end{array}$ & [33] \\
\hline \multirow{5}{*}{$\begin{array}{l}\text { Green warehousing } \\
\text { Reduce, recover, reuse } \\
\text { Effective use of by products } \\
\text { Life-cycle analyses } \\
\text { Adopting certification and } \\
\text { standards }\end{array}$} & \multirow{4}{*}{$\begin{array}{l}{[34]} \\
{[35]} \\
{[37]} \\
{[39]}\end{array}$} & \multicolumn{2}{|c|}{ External Socially Responsible Practices } \\
\hline & & \multirow{3}{*}{$\begin{array}{l}\text { Buying local } \\
\text { Stakeholder safety } \\
\text { Social inclusion and contributions to }\end{array}$} & [36] \\
\hline & & & [38] \\
\hline & & & [8] \\
\hline & [23] & \multirow[t]{2}{*}{ community Resource Optimization } & \\
\hline \multicolumn{2}{|c|}{ Internal Socially Responsible Practices } & & [17] \\
\hline $\begin{array}{l}\text { Employee health, wellbeing, and } \\
\text { safety }\end{array}$ & [40] & Quality management & {$[14,15]$} \\
\hline $\begin{array}{l}\text { Employee training and } \\
\text { opportunities for growth }\end{array}$ & [41] & Lean practices & [16] \\
\hline $\begin{array}{l}\text { Labor conditions, human rights, } \\
\text { and gender equality }\end{array}$ & [8] & & \\
\hline
\end{tabular}

NGO-non-governmental organization.

The organizational and supply chain actors are influenced by a wide variety of SSCM motivations, ranging from stakeholders [9] to competitive and strategic pressures. Customer and the society expectations led developed economies to move toward a more strategic orientation of SSCM [10], whereas emerging economies are largely driven by state laws and the export country's regulations [11]. The degree to which a business focuses on internal and/or external sustainability practices is also context-specific; developed countries put greater emphasis on collaboration along the supply chain with a focus on supplier engagement and development for SSCM [12]. The mainly compliance-oriented SSCM in emerging economies was shown to focus on the internal sustainable practices for the Chinese manufacturing industry [13]. There is also a parallel stream of literature that recognizes operations management's best practices such as lean and total quality management as contributing to SSCM. Companies having high levels of adoption of quality management practices are likely to achieve superior environmental performance $[14,15]$. Similarly, companies with a more mature lean implementation are likely to yield a high extent of environmental practices [16]. Lean Six Sigma in conjunction with green supply chain management helped organizations to averagely reduce their resource consumption from 20 to $40 \%$ and minimize the cost of energy and mass streams by $7-12 \%$ [17]. However, all these studies took an integrative perspective, and the reported evidence was obtained by examining the relationship between traditional resource optimization approaches, such as lean and Six Sigma, and sustainable supply chain management. 
The contextual differences highlight the SSCM challenges, as global supply chains now must manage the shifting roles, motivations, and foci of SSCM transformational actors along the supply chain [5]. The literature suggests that the emerging economy SSCM research requires constructs that reflect the emerging economy's technological and infrastructure development [42], government regulation [9], available skill levels [41], resources [43], and research and design capability [44]. A greater understanding of the constructs that affect SSCM in emerging economies is likely to provide improved standards of living [45,46], use of resources [47], sustainable policy development [42], industry innovation, and local capability development [4], as well as reduce the current rate of resource consumption [48]. Identifying the actors, their motives, and the actions that constitute SSCM initiatives in emerging economies will provide the best basis for developing these constructs [23,49]. Analyzing data from the large range of actors, systems, and organizations that can be engaged in SSCM initiatives requires a flexible and critical analysis approach. AT is an effective analysis method for identifying the interactions, motivations, and actions of a broad range of actors in relation to specific initiatives [50]. The theory and application of AT is now described.

\subsection{An Introduction to the Activity Theory}

AT theory focuses on organizational practices [51,52] which makes it a suitable approach to examine sustainability practices and initiatives. An AT analysis focuses on what managers "do" while making decisions, managing situations, and organizing activities to support an overarching goal. AT theory can link individual activities with those of institutions, whilst maintaining a focus on the actors and their potential for agency [53]. AT can be used to analyze management activity systems by contextualizing the dynamic and mediated relationships as individuals work toward a shared goal [54].

As shown in Figure 1a, AT addresses three sets of relationships. Tools mediate the relationship between the subject and the object, rules mediate the relationship between the subject and the community, and the division of labor mediates the relationship between the community and the object. The context for all of these relationships is that they are directed toward the specified outcome of the activity. AT theory also includes a hierarchical perspective of the relationships representing why and how the activity occurs, portrayed in Figure 1b. AT considers an activity as a three-level, usually collaborative, construct with a strategic motive. The activity is carried out through the actions of the subject(s) which are directed toward an object. An action is a task that is performed to achieve the activity's intended outcome activity (goal) and comprises a sequence of operations or routine work functions.

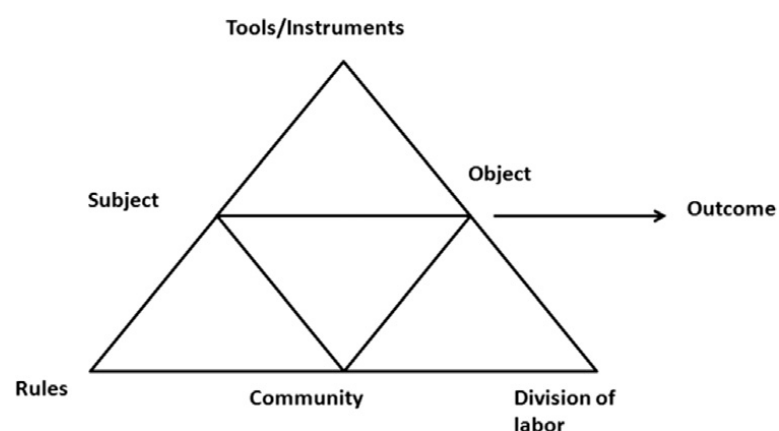

a. Basic structure of an activity

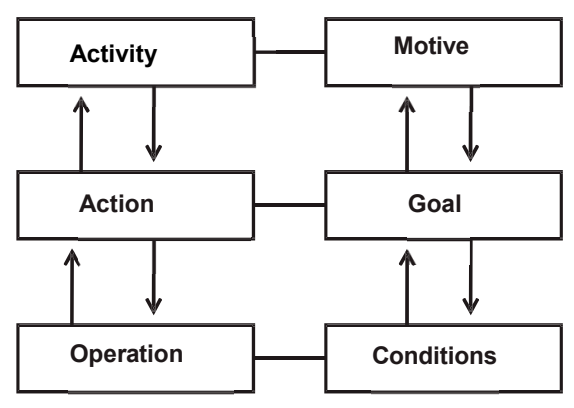

b. Hierarchical structure of an activity

Figure 1. Activity theory structure.

The AT analysis framework assumes that the success of "activities" is dependent on cooperation between both internal and external actors. This is a valid analysis perspective for SSCM in emerging economies for which the literature review identified a need to develop constructs representing how individuals and organizations interact at the individual, group, and institutional levels $[55,56]$. AT was used as an analysis framework in a range of management discipline studies, including 
strategic management [7,50], corporate social responsibility [57], community services [58], knowledge management [59], service development [51], and operations management [60].

\subsection{The Emerging Economy Context-United Arab Emirates}

The United Arab Emirates (UAE) is classified as an emerging economy by the Morgan Stanley Capital International (MSCI) since 2013 (https://www.msci.com/market-cap-weighted-indexes). The MSCI uses a composite benchmark comprising environmental, social, and governance indicators for their classification, and it currently has 24 countries listed as emerging markets. The UAE is a unique emerging economy because of its high gross domestic product (GDP) per capita comparable to most developed economies. The UAE saw rapid development fueled primarily by oil revenues; however, it still faces challenges for sustainable economic growth such as reliance on oil and a shortage of a skilled workforce within the small local population. The shortage of skills and a small local population meant that the workforce was historically sourced from overseas and, currently, $85 \%$ of the UAE workforce comprises expatriate workers. The population is estimated to be nine million, and the demographic makeup is $11.9 \%$ locals, $59.4 \%$ South Asians, $10.2 \%$ Egyptians, $6.1 \%$ from the Philippines, and $12.8 \%$ others. The expatriate demographics are also dispersed across managerial levels; the Westerners and Western educated expatriates generally fill in senior and middle managerial positions, and lower management positions are largely occupied by Arab and South Asian expatriates, whereas the non-skilled labor is mainly sourced from South Asia, the Philippines, and Indonesia. Labor laws safeguard workers' rights, but there is no minimum wage enforced by the government. The wages are determined by market forces, which keeps a segment of the population (mainly the non-skilled workforce) at poverty line wages [61].

The UAE government is cognizant of the sustainable development challenges it faces. Over the years, oil revenues were spent to develop UAE's infrastructure and human resources. More recently, the government affirmed its commitment to sustainable economic growth through the UAE Vision 2030 by identifying sustainable environment and infrastructure and social inclusion as the key priority areas [62]. A range of countrywide initiatives were undertaken by the government, and incentives were given to the private sectors to incorporate sustainable practices in their areas of influence. In this backdrop, we collected data from 16 organizations to examine the SSCM initiatives.

\section{Methods}

To understand how sustainability initiatives are implemented in an emerging economy, this study adopted a qualitative approach and AT as the analysis framework. A qualitative approach is recommended when a rich understanding of a phenomenon under study is required [63]. We also wanted to extrapolate our research findings to the UAE context by finding common themes across a range of supply chains. The AT framework in conjunction with hybrid inductive-deductive thematic analyses [64] enabled this. The inductive-deductive thematic analyses involved two stages. Firstly, the qualitative themes were identified in the AT construction of individual organizations. Then, these qualitative themes were grouped into a more generalizable AT subcategory of themes. The AT subcategories were inspired from the literature summary provided in Table 1. For example, the actions and practices were subcategorized under internal or external social and environmental subcategories of the AT tools. This facilitated a comparative analyses of AT subjects, objects, motives, tools, rules, and community actors across multiple supply chains. Illustrative examples for three organizations are presented later in this section to explain this methodology.

We purposefully identified 16 different organizations in the United Arab Emirates to represent a range of supply chains such as hospitals, hotels, manufacturing, and governmental services. The data were collected from multiple sectors in order to achieve sufficient variation in the SSCM implementations. The selection of these organizations was based on the criterion that a sustainability initiative was implemented in their supply chains for at least one year. Within these organizations, we approached managers who were directly involved with the supply chain functional areas for 
a semi-structured interview. The units of analysis were the sustainability initiatives taken by the companies that corresponded to the activity tier of the AT hierarchical levels. Demographics of the participants included procurement managers, purchasing managers, general managers, and supply chain manager (Table 2). The interviews were recorded and transcribed to facilitate qualitative analysis. The interviews lasted 60 to $90 \mathrm{~min}$. To triangulate the subjective responses of the interviewees, objective sources of data, such as company reports and company website data, were also collected to validate and confirm the interview data.

Table 2. Participant organizations.

\begin{tabular}{ccccc}
\hline Organizations & Industry & Sector & Personnel Interviewed & SSCM Years \\
\hline 1 & Healthcare & Private & Material Management Manager & 5 \\
2 & Hotel & Private & Purchasing Manager & 6 \\
3 & Tourism & Public & Director of Procurement Services & 1 \\
4 & Food control & Public & Strategy and Performance & 5 \\
5 & Energy & Private & Engineer in Charge & 9 \\
6 & Military & Public & Operations Manager & 6 \\
7 & Telecommunication & Public & Materials Manager & 9 \\
8 & Municipality & Public & Acting General Manager & 1 \\
9 & Furniture & Private & General Manager & 11 \\
10 & Water & Private & General Manager & 1 \\
11 & Airline & Private & Sustainability Head & 13 \\
12 & Retail & Private & General Manager & 20 \\
13 & Marine & Private & Supply Chain-Team Leader & 10 \\
14 & Hotel & Private & Chief Operations Engineer & 4 \\
15 & Water \& Electricity & Public & Supply Manager & 9 \\
16 & Transmission & Private & Procurement Manager & 1 \\
\hline
\end{tabular}

\subsection{Case A: Hospital $X$}

Figure 2 illustrates the AT analysis findings for the data from Hospital X. The subjects were from the procurement department and the human resource department. The objective was to make the hospital's supply chain more sustainable. Social sustainability was prioritized by the hospital, reflecting its community role. In addition to ensuring a high level of community health capability, the procurement department balanced the impact of input costs (which affected the ability to provide health services to the community) and supply chain environmental impact, as described in the following quotation:

"Yes, since we are working within healthcare facilities, and one of our priorities is the healthcare system. The function involves our procurement managers analyzing and evaluating the cost of the items that we are going to procure, and, at the same time, determining the impact on human health and on the environment. We fully coordinate with end-users (surgeons/nurses/technicians). It is important here to mention that we follow the Ministry of Health and HAAD guides."

The activity tools used to attain the AT object were management systems, internal procedures and policies, and work standardization systems. The hospital also collaborated with the Health Authority Abu Dhabi (HAAD) to recruit more local healthcare professionals, in support of the UAE government's objective of building a sustainable healthcare supply chain [62]. Implementing SSCM was a challenge because of the need to keep costs in control. Other barriers experienced were the need to train employees in sustainability, creating a supply chain culture, and gaining the cooperation of suppliers. Cooperation with outside institutions was important, as the following quotation indicates:

"Awareness about green marketing/products, and sustainable SCM/future purchase behavior of products will be increased, since that supports life and human beings. The regulations/culture can also play the important role of developing activity. I think the institutes who are offering the training in green supply chain management can also play a main role to develop this field." 
Tools Procurement material management policy and

procedures, procurement KPIs, environmental, health

and safety management system, international standards

Subject: Procurement department Human Resource department

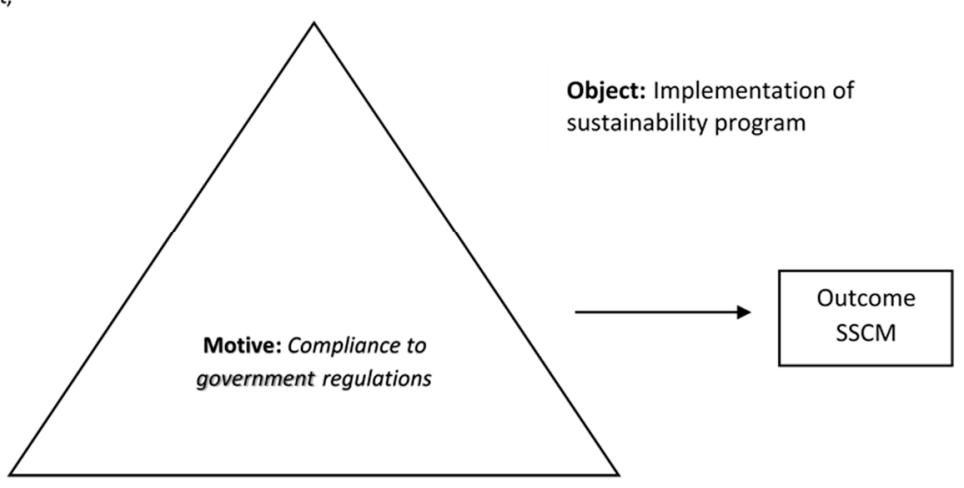

Rules: HAAD \& SEHA Regulations, JCIA Standards
Community: UAE Healthcare Facilities, International Institute for Best Practices
Division of Labour: Doctors, nurses and other staff members

HAAD $=$ Health Authority Abu Dhabi, SEHA= Abu Dhabi Health Services Company, JCIA= Joint Commission International Accreditation, KPIs = Key Performance Indicators.

Figure 2. The basic activity structure for Hospital X.

Figure 2 illustrates the analytical unit of AT, i.e., the activity system with an object or purpose of implementing the SSCM initiative at the hospital. The subjects, i.e., the procurement and the human resource departments, are working toward the AT object. The health regulating bodies in the UAE, the Abu Dhabi Health Authority (HAAD) and the Abu Dhabi Health Services Company (SEHA), enforce the rules toward the object for the hospital, and we classified the HAAD and SEHA as the community actors that provide the AT rules for the subjects. The HAAD and SEHA collaborated closely with the hospital for the recruitment of local doctors. The aim was to build a foundation of healthcare in UAE with local talent that would ensure a sustainable healthcare system. The relationship between subject and object is mediated by tools helping subjects attain the object. The division of labor was between the doctors, nurses, and other staff members that provided support to the SSCM initiative. This included coordinating with the end users to evaluate activities related to the cost of items to be procured, as well as the impact on the health and safety of patients.

The other significant community actor that affected the SSCM initiatives was the Joint Commission International Accreditation (JCIA-accrediting authority for hospitals under SEHA). The hospital ensures standard quality services to their patients for sustainable performance by adopting the best practices recommended by the JCIA. The interviewee mentioned that the company integrated these sustainable measures for the last five years, and some of the initial motives that drove the activity were patient safety in the hospital and prioritizing healthcare systems according to the government-prescribed rules and procedures. This allowed us to identify compliance with government policy and regulations as the AT motive.

The AT representation for Hospital X was followed by stage 2 of the inductive-deductive coding by grouping the identified themes in more generalizable AT subcategories identified by the literature in Table 1. For example, the sustainably program targeted patient safety, environmental responsibility, and compliance with the government's environmental and social policy measures. Therefore, two subcategories of AT objects for Hospital X were identified, namely, social and environmental sustainability. The subjects were the procurement and the human resources departments-both implementing a series of measures classified as AT tools. The procurement and material management measures were classified as both external and internal socially responsible measures because they involved external interactions with suppliers and internal implementation within the hospital. The 
human resources measures that encouraged the recruitment of local workforce were also classified as an external social practice. The implementation of environmental, health, and safety management systems was classified as an internal practice that had both social and environmental dimensions. The implementation of international standards was seen as an internal social practice aimed at improving patient safety. Two broad categories of community actors were identified that enacted rules and policy measures that assisted Hospital X in implementing SSCM. The government health regulating bodies in the UAE, such as the HAAD and SEHA, and the international standards and accreditation organizations, such as JCIA, formed the broader community of healthcare facilities that affected the sustainability program. The AT subcategories for Hospital X and the other 15 cases that helped construct an AT structure for all 16 participant organizations are provided in Table 3.

Table 3. The frequency of identified activity theory (AT) subcategory themes.

\begin{tabular}{|c|c|c|}
\hline AT Category & AT Subcategory & Frequency * \\
\hline \multirow{5}{*}{ Subject } & Procurement/supply chain department & 6 \\
\hline & Sustainability & 1 \\
\hline & General management department & 5 \\
\hline & Engineering & 2 \\
\hline & Multiple departments & 2 \\
\hline \multirow{3}{*}{ Object } & Environmental sustainability & 15 \\
\hline & Social sustainability & 3 \\
\hline & Economic sustainability & 8 \\
\hline \multirow{5}{*}{ Tools } & External environmentally friendly practices & 11 \\
\hline & Internal environmentally friendly practices & 15 \\
\hline & Internal socially responsible practices & 3 \\
\hline & External socially responsible practices & 2 \\
\hline & Resource optimization & 6 \\
\hline \multirow{3}{*}{ Rules } & Government Policy and regulations & 13 \\
\hline & International best practices & 10 \\
\hline & Organization policies & 7 \\
\hline \multirow{3}{*}{ Community } & International institutes for industry best practices & 10 \\
\hline & International—group head office & 5 \\
\hline & Local institutions & 16 \\
\hline \multirow{4}{*}{ Motive } & Compliance with government vision and regulations & 10 \\
\hline & CSR policy & 6 \\
\hline & Customer legitimacy & 5 \\
\hline & Financial benefits & 2 \\
\hline
\end{tabular}

* Refers to the number of participant organizations reporting the presence of the AT subcategory theme.

\subsection{Case B: Hotel X}

Hotel $\mathrm{X}$ is a five-star hotel in Abu Dhabi, and the sustainability initiative's basic activity structure is given in Figure 3. The subject represents a team implementing the "Planet 21" program at the hotel. Multiple departments in the hotel worked with the Planet 21 team, and all departments in the hotel were expected to contribute. The program was initiated via collaboration with its international group head office which we classified as the community actor affecting the SSCM initiatives by drawing out rules for implementation. Under this program, hotels undergo sustainable transition which focuses 
on four strategic priorities: employees, customers, society, and suppliers. It was initiated at the Rio Earth summit in 1992 with the aim of sustainable growth development by the 21st century to conserve and preserve the environment and eco system. The hotel implemented this for four years. Major tools that were utilized in this process were mentioned in the interview as surveys, policies, procedures, and technology implementation. The interview claims were also corroborated through secondary data from the hotel's group website. The motivations for implementing Planet 21 were to ensure employee health and safety, work-life balance, customer satisfaction, and reduction of environmental footprint, as well as to improve quality. In line with our inductive-deductive coding, employee health and safety and work-life balance were motivated by the hotel chain's corporate social responsibility (CSR) agenda; therefore, the hotel's CSR policy was identified as the principal motive. The customer legitimacy was the second motive identified for organization 2 that constituted a higher-level theme for sustainability motivations that included both superior customer service and customer pressures to implement sustainability. For example, our respondent noted, " ... the hotel industry is changing over time; (sustainability) is driven by global competition and increasingly high customer expectations". The customer legitimacy motive had an economic undercurrent because of a potential loss of business if the customer expectations on sustainability were not addressed. This led us to the three AT object subcategories of environmental, social, and economic sustainability. A key element of the Hotel X sustainability strategy is the active engagement of customers, which is implemented through technology. For example, our respondent mentioned the following:

"... creating a mobile white space app that makes it easy for the guest to interact quickly with the hotel, and allows them to give their feedback and suggestions if they have any comments (on sustainability) to provide the guests with a high level of satisfaction and an increase in engagement."

Tools: Surveys, policies, procedures, training, technology implementation

Subject: Planet 21 Team

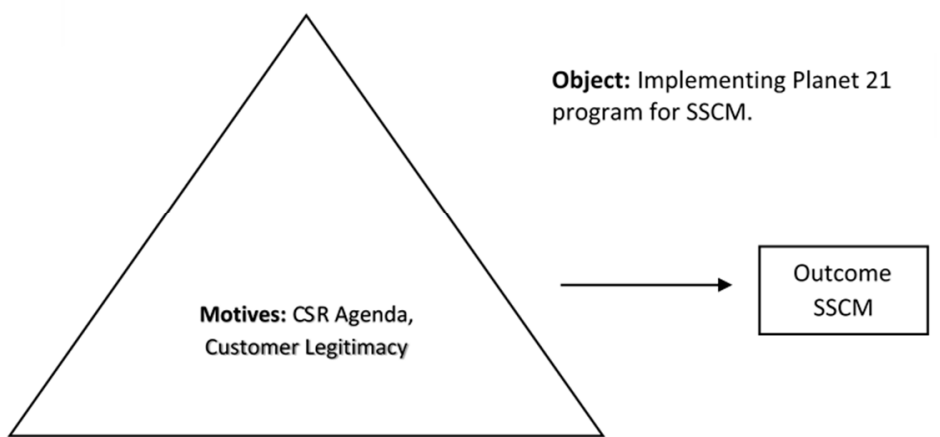

Rules: Government policy and regulations, International best practices

Community: International group head office, local institutions
Division of Labour: Marketing, IT, operations, $\mathrm{HR}$

CSR = Corporate Social Responsibility, HR = Human Resource, IT = Information Technology

Figure 3. The basic activity structure for Hotel X.

Other AT tools implemented by Hotel X were staff and customer surveys, policies, procedures, and training for staff and suppliers. Lack of sustainability awareness of local suppliers was also noted as a barrier by our respondents: "suppliers do not seem to understand the importance ... they care only about the profit". In line with our inductive-deductive coding, the AT tool's subcategories were grouped into external or internal environmental and internal social practices. In addition to the international group head office role in the SSCM initiative, the interviewee also reported UAE sustainability regulations that the hotel needs to comply with. Therefore, the local institutes within the UAE were also coded as community actors. 


\subsection{Case C: Cultural and Tourism Authority—Supply Chain}

The Tourism and Cultural Authority (TCA) attempted to instill sustainability in the supply chain through their procurement department and Khalifa fund initiative. The Khalifa fund initiative provides a platform for young locals to initiate entrepreneurial opportunities within UAE that can help sustain business for small and medium enterprises (SMEs). TCA provides SMEs with training, consultation, and market-focused services. The subject in this activity is the procurement team that collaborates with Khalifa fund to get databases of suppliers to support local companies and encourage their participation in the bidder lists for TCA tenders. The interviewee stated that, by incorporating local suppliers in the bidding, the authority supports the local community, a cornerstone of social practices.

"... it is the sum of 'individual' behaviors that helps the organization to achieve sustainability, and we need to increase the sense of responsibility that comes with spending government money in support of the UAE's people, businesses, and environment."

The Tourism and Cultural Authority's SSCM activity structure is shown in Figure 4. The sustainability program was delivered through their Khalifa fund. The Khalifa fund enabled the authority to create supply contracts with young local sustainability-focused entrepreneurs. The subject was the procurement team that encouraged local entrepreneurs to bid for program tenders.

Tools Pearl rating system, supplier's code of conduct

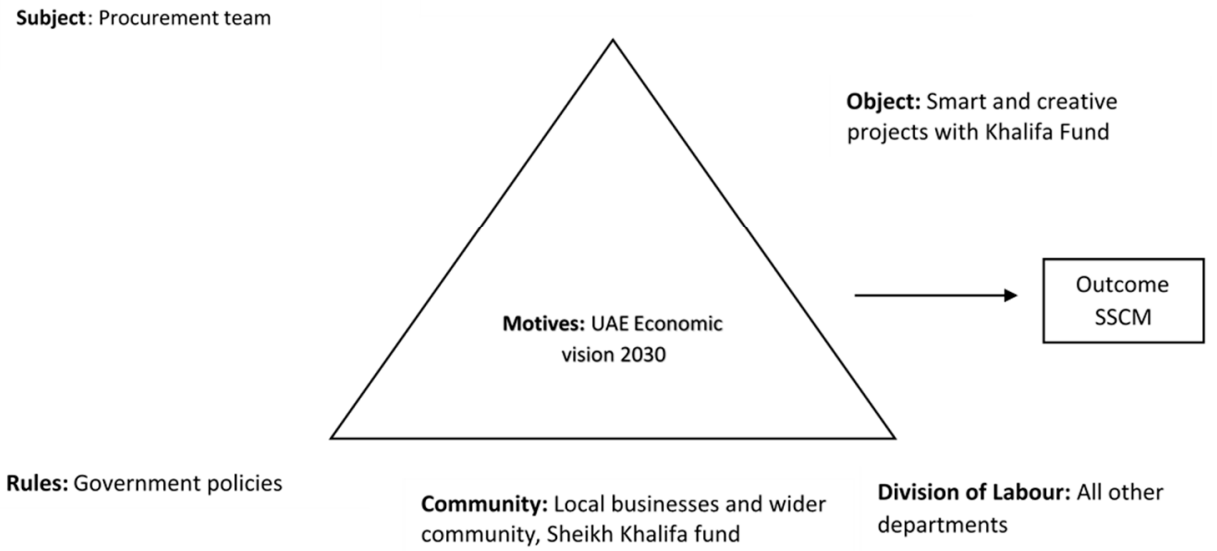

Figure 4. The basic activity structure for the Tourism and Cultural Authority.

The tool used to achieve this object was a code of conduct for the project participants. The program helped local entrepreneurs to become sustainable suppliers, and all procurement teams and administrative staff were involved. The program was considered to be important because most suppliers in the region were profit-oriented and not sustainability-oriented. The authority used its supplier prequalification process to encourage more suppliers in the region to become sustainable suppliers, as indicated by the following quotation from their website:

"Suppliers must provide a safe and healthy working environment that complies with occupational health, safety laws, and environmental policies and practices."

The government's 2030 economic vision was the key motivation for the program which led to an AT object of social sustainability. The vision also provided the policies used in the program, as the following quotation indicates:

"Sustainability is a key theme in the UAE Economic Vision 2030 and, as a government entity, TCA has an ethical and moral responsibility to ensure that government money is wisely spent and supports the local economy and its people, while protecting and enhancing the environment." 


\section{Results-The Basic Activity Structure for the Complete Dataset of 16 Organizations}

We repeated the activity theory constructions with inductive-deductive coding for all 16 participant organizations. Table 3 presents the summary of the 16 AT constructions of SSCM initiatives. Compliance with government vision and regulations was the principal motive for the SSCM adoption in the study sample, with 10 of the companies referring to it. In addition to organizations 1 and 3, organizations $4,5,8,13$, and 15 mentioned compliance with the government as the sole motive for their SSCM. For example, the respondent from organization 8 stated, "we have a (government) vision called (2030) that we see our future within it for all the service and demand practices". Similarly, the respondent from organization 5 stated, "... (we are) working on the idea of renewable energy and supporting the UAE initiative to achieve $7 \%$ of its total energy demand from renewable resources by 2030." These six organizations were either government agencies or privately owned local businesses, and one of their key attributes was their reliance on government guidelines to implement SSCM as they did not develop their own organizational policies for sustainability implementations. Organizations 6 and 7 also mentioned the financial benefits of implementing SSCM as the AT motive. The respondent from organization 7 stated, "a system that helps to minimize carbon by around $3 \%$, reduce around $4.2 \%$ of water use ... saves cost (more cost-effective)".

Organizations 1, 5, 8, and 15 utilized local and international best practices as AT rules for SSCM implementation. For example, organization 8 referred to the use of key performance indicators (KPIs) and the global reporting initiative (GRI) index as the AT rules: "... the use of KPIs, which allows both the environmental agency and us to distinguish indicators ... to have the greatest impact... We provide a table of contents, a GRI index." Similarly, the respondent from organization 15 also highlighted the international institutions for best practices as the source of AT rules for its SSCM in the following manner: "The company continues its efforts to obtain international certifications such as Pas55 and ISO 55000 with the objective of achieving its vision and making the required cultural and organizational change".

Organizations 2, 9, 12, 14 and 16 mentioned customer legitimacy and CSR policy as the two principal motives for SSCM initiatives. These organizations are part of multinational companies (MNCs) operating in the UAE with a high degree of customer exposure. The international group head office was a key community actor for all five companies that enacted AT rules for SSCM implementation. For example, the respondent for organization 14 noted, "it's (SSCM) a corporate initiative which is driven by the corporate (international) main head office". Similarly, organization 12 stated, "the company responds to sustainable development issues ... by implementing (central) CSR policy to benefit the stakeholders". Organization 11 is a large government-owned company with significant international operations, and it mentioned both the CSR policy and compliance with government regulations as the two motives for its SSCM. Our respondent highlighted the government's vision as the overarching reason for its CSR agenda in the following manner: "the UAE government is so keen on being the leader in sustainable development. It was $U A E$ and Abu Dhabi who said we want to be the leader in renewable energy ... and it shows our commitment to more of our CSR agenda". Organization 11 also highlighted the importance of organizational policies that draw on both government regulations and international best practices to guide the SSCM initiatives. Consequently, we coded organizational policies, government policy and regulations, and international best practices as the three sources of AT rules.

The key AT subcategories shown in Table 3 were then arranged within the activity framework to construct the AT diagram for all 16 organizations (Figure 5). This figure shows that the subjects initiated the SSCM initiatives and had a significant level of control. Government policies, organizational policies, and international institutes for best practices were identified as the sources of rules connecting the subject and the community. A range of social, environmental, and resource optimization AT tools for implementing SSCM were identified as connecting the subjects and the objects. The division of labor as a connection between objects and the community comprised intra and inter-organizational collaboration. Compliance with government vision, CSR agenda, customer legitimacy, and financial benefits were identified as the four principal motives for SSCM in the UAE. The frequencies of AT 
constituents are mentioned in Table 3. The details of each organization's SSCM initiative under the three AT hierarchy levels (activity, action, and operation) are provided as Table A1.

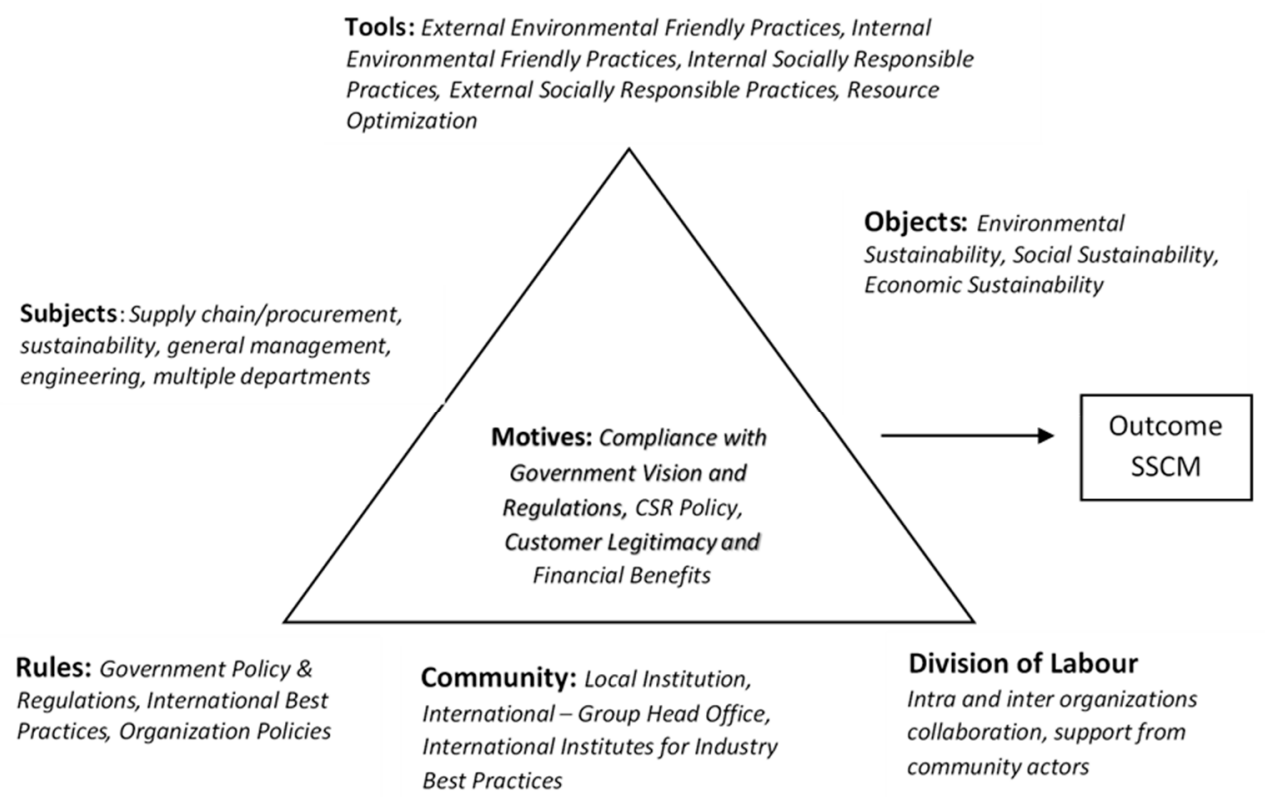

Figure 5. The basic activity structure for the complete dataset of 16 organizations.

\section{Discussion}

We investigated sustainable supply chain initiatives for 16 organizations as part of an activity system involving socio-cultural interactions mediated by tools, rules, and division of labor. One key research objective was to comprehend motives and actions that improve the sustainable performance of supply chains in the UAE and to compare them with similar emerging economies and the developed world. Similar to our findings, the stakeholder pressure is a key driver toward the industry's sustainability push in the Western world; however, there are significant differences too. For example, Walker and Jones [3] surveyed British businesses who identified customer pressure as the top external enabler toward sustainability, followed by the investors' interest and non-governmental organization (NGO) activity. Similarly, Vieira and Amaral [65]'s literature review on external enablers for cleaner production identified social pressure as the top driver for sustainability. This contrasts with our findings where the government vision and regulations were the overriding motive for sustainability (organizations 1, 3, 4, 5, 6, 7, 8, 11, 13 and 15). The customer legitimacy was identified as the second most common motive by five organizations, but these were MNCs (organizations 2, 9, 12, 14, and 16), representing an international outlook on sustainability.

We checked sustainability initiatives in other emerging countries to identify the principal stakeholders driving the sustainability transitions, and we saw government regulations as the dominant influencer for sustainability adoption [5]. For example, similar to the UAE Vision 2030, the Chinese government identified sustainability as a strategic priority and, since then, a host of policy measures were introduced, including laws, to coerce the adoption of sustainable measures [11]. The critical role of government regulations for sustainable production was also highlighted for other emerging countries such as India [66] and Brazil [4]. The literature on SSCM in emerging economies started to highlight the role that governments play in enhancing the sustainability capability of industrial production systems such as instituting sustainability promotion centers and sustainability audits, as well as the publication and dissemination of best management practices [67]. The AT constructions employed in our research enabled us to identify the dual mediating effects of government on SSCM as a dynamic relationship. The government firstly motivated the adoption of sustainability practices as confirmed by 10 participant organizations (Table 3). Table 3 also lists local institutes such as government departments 
and agencies as community actors that provided AT rules for all 16 organizations. For example, the respondent from organization 11 noted, "government support was an important factor in progressing on sustainability." This shows that the government also acts as a facilitator by providing active support to increase organizational capabilities to implement SSCM practices. The dual effect of the government's influences on SSCM is a new and significant finding that the literature is yet to fully appreciate. This leads us to generalize our findings to other emerging and developing economies, and we put forward the following proposition:

Proposition 1. The sustainability initiatives in emerging economies are positively mediated by both government regulations and support. The government enacts regulations to firstly motivate the adoption of SSCM, and then it provides directions and active support to facilitate the implementation of SSCM by helping build organizational capabilities.

The centerpiece of the triple bottom line approach is that it "pays to be green and socially responsible", at least in the long run [68]. However, there seems to be a narrow and short-term view on this in emerging and developing economies, where managers often perceive sustainable measures as costly [66]. For example, the participant representing organization 14 identified capital expenditure, competitive forces, and a lack of supplier knowledge as external barriers to SSCM initiatives: "There are many difficulties that the hotel faced. To start with, the high cost of equipment (financial) that helps to save energy and minimize waste is not well aligned with the goals of sustainability. Secondly, one external barrier is that customers are always looking for low prices." The respondents also highlighted what they perceived as a paradox of going green and yet meeting their cost-saving targets. For example, organization 5 indicated, "trying to find external funding for renewable energy projects and collaboration with industries at some point is difficult ..." This suggests that the participants were unwilling to pay for the extra expense required to bring in all resources and the knowledge to assist them with the implementation of SSCM, because the sustainability benefits may not be apparent or quick enough to achieve. This was consistent with the finding that SSCM was considered to be an operational expense in India [66]. It contrasts with the evidence, however, from SSCM initiatives in developed economies, where SSCM was found to reduce operating costs [68]. SSCM benefit analyses in developed countries included cost accounting [69], total cost of ownership [70], and sustainability assessment models [71]. These analysis techniques determined sustainability initiatives to be a value-adding activity by identifying the true cost of unsustainable operations, such as the cost of environmental impact. This leads to the following proposition:

Proposition 2. The sustainability initiatives in emerging economies are positively mediated by accounting for the costs associated with the "unsustainable" measures. Decision-making approaches such as life-cycle analyses would help improve businesses' awareness in emerging economies to view sustainability as a strategic opportunity rather than as an operational expense.

The "end to end" concept of value chains underscores the need for the superior environmental and social performance of the supplier for an overall sustainable supply chain. However, the sustainability dimension of a supplier's performance is not as easily evident as the traditional performance measures of cost and quality. This factor, combined with the often unclear delineation between the traditional competitive and sustainable priorities within the focal company, may further complicate the collaboration with suppliers on sustainability. Seven respondent organizations identified the supplier's sustainable performance as a barrier to SSCM. For example, the organization 10 interviewee stated that, "our key suppliers, many of them do not have clear definitions of what a sustainable supply chain is. Many of them are hesitant to implement this practice because they are considering the cost as well". The participant representing organization 16 also stated that, "suppliers do not understand the importance of the new concept ... They prefer profit and benefit over sustainability... " The perception amongst suppliers of sustainability as an operational cost is an externally located barrier to the 
adoption of SSCM. One pragmatic way to deal with this dilemma is to treat sustainability as an "order qualifier", i.e., the suppliers need to exhibit certain environmental and social behavior so that their products or services may be deemed fit for purchase by consumers [72]. Our research shows that the participant organizations realize this by putting a high emphasis on formal measures such as certifications and audits in place for their suppliers. Five organizations represented in the study developed formal criteria for the environment sustainability of their suppliers. These formal criteria included the development of environmental sustainability policies and the requirement that suppliers have sustainability certifications. Three of these policies (organizations 2, 14, and 16) were developed for the companies by the UAE government's sustainability authority. A fourth (organization 8) developed key performance indicators (KPIs) for their SSCM based on the global reporting initiative (GRI) index. The voluntary certification of the suppliers as evidence for sustainable performance is akin to the best procurement practices widely followed in developed economies [19]. This leads us to put forward the following generalized finding as our third research proposition:

Proposition 3. The sustainable initiatives in emerging economies are positively mediated by the inclusion of sustainability as an "order qualifier" for their suppliers by stipulating a minimum acceptable supplier performance in sustainability.

Prior research on what drives firms to embrace sustainability divided the facilitating and inhibiting factors as internal and external to the focal business [3]. Vieira and Amaral [65] termed the socio-cultural interactions between the human subjects involved in sustainability initiatives as the main internal challenge. Employee awareness and training on sustainability was identified as an important tenet of cleaner production and consumption for the SME sector in the Netherlands [73] and in the United States $[74,75]$. We observed similar patterns in our research. Employee training and their acceptance of the introduction of sustainability measures, which may in turn generate their commitment to the sustainability targets, were identified as key factors for our study sample. For example, the respondent from organization 7 said, "we conduct many training programs to increase the awareness among employees." Similarly, organization 11 highlighted the role that international institutes for best practices play to improve the awareness of their employees: " ... we bring people in and we have workshops like the CSR Asia workshop (for employee training)."

To elicit the right employee attitude toward sustainability, both cooperative and coercive measures are employed across the globe; however, the broad agreement is that "influence without authority" ensures the "sustainability of sustainable measures". Jayanti and Rajeev Gowda [66] maintained that senior managers must lead by example to convince their staff and coworkers by resorting to a mix of emotional appeals and rational arguments that are supported by facts and figures. The authors stressed the need for fully harnessing the potential of their human capital by employing innovative ways to maximize the sustainable performance of their respective sphere of influences. Our research also revealed similar insights, as the staff's active engagement is seen as critical to sustainability improvements. This approach may be another unique construct for SSCM in emerging economies and leads to the following proposition:

Proposition 4. The sustainability initiatives in emerging economies are positively mediated by the employee transition from compliance to taking the ownership of sustainability initiatives.

\section{Conclusions, Limitations, and Directions for Future Research}

The focal point of the study was to investigate the barriers and enablers faced by companies in the UAE while implementing sustainable supply chain practices. Sixteen organizations were chosen for this investigation, both from public and private sectors, having at least one year of experience in implementing sustainability initiatives. The objectives of the study were directed to understand three aspects of SSCM: stakeholder interactions, tools and outcomes, and motives and actions. These 
objectives were achieved through the application of activity theory. The theory provides a solid ground on understanding the social side of an activity by undertaking not only the technical but also the human elements. The factors identified in the literature with respect to enablers and barriers corroborated our findings. Our study found similar enablers such as training staff, supplier involvement, public sector policies, cost reduction, and competitive advantage. On the other hand, for the barriers, new factors such as uninformed supplier capabilities and funding issues were identified. The highlights of our research are the four propositions that identified the key contributors to successful sustainability outcomes in the context of emerging economies: (a) the dynamic influence of governments on the adoption and implementation of SSCM; (b) accounting for the costs associated with "unsustainable" measures, which enables a strategic perspective on sustainability; (c) the inclusion of sustainability as an "order qualifier" for their suppliers; and (d) the employee transition from compliance to taking ownership of sustainability initiatives.

One limitation faced in the study was the number of organizations, which had ramifications for the generalization of our results. Although we used 16 companies to deeply understand the sustainability initiatives with multiple sources of data, the issue of generalization remains. However, we were able to relate our research observations to past studies that led us to put forward our four research propositions. Companies were chosen based on their involvement in SSCM activities; thus, they cannot be regarded as sustainability leaders within their industry. Our study exclusively studied companies in the UAE; however, the results may be applicable to other emerging economies as our findings did corroborate with previous studies.

There is a need for future research on a wider scale for companies implementing sustainable measures within the emerging and developing world. It would be an interesting angle to see how various industries across geographical locations differ in terms of supply chain practices and the practitioner's perceptions of the sustainability enablers and barriers. This research study provided a viewpoint from the focal company's side, it would be useful for other researchers to examine the network from the supplier's side as well. Adding to this, the factors of other key stakeholders, such as investors and end users, that influence a company's SSCM practices can also be investigated.

Author Contributions: S.A. collected the data and performed data analyses. M.M. conducted the literature review and wrote the paper.

Funding: This research received no external funding.

Acknowledgments: This research was funded by Abu Dhabi Education Council grant number 2015 and the APC was funded by Abu Dhabi University.

Conflicts of Interest: The authors declare no conflict of interest.

\section{Appendix A}

Table A1. The details of each organization's SSCM initiative under the three AT hierarchy levels.

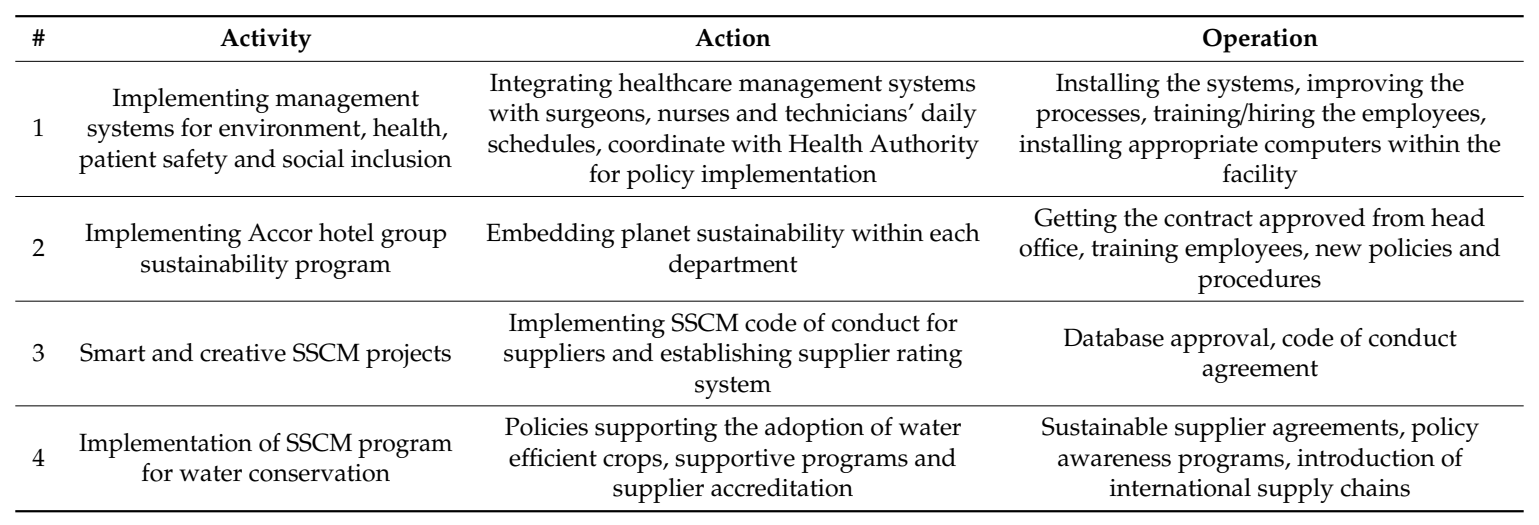


Table A1. Cont.

\begin{tabular}{|c|c|c|c|}
\hline$\#$ & Activity & Action & Operation \\
\hline 5 & $\begin{array}{l}\text { Getting ready for generation of } \\
\text { renewable energy by } 2021\end{array}$ & $\begin{array}{l}\text { Installation of power plants, ensuring } \\
\text { compliance with government rules and } \\
\text { policies, collaborating with other industries }\end{array}$ & $\begin{array}{l}\text { Developing investor trust, purchasing and } \\
\text { installing equipment, monitoring costs }\end{array}$ \\
\hline 6 & $\begin{array}{l}\text { Sustainable logistics and } \\
\text { procurement system } \\
\text { implementation }\end{array}$ & $\begin{array}{l}\text { Managing inventory, system integration, } \\
\text { documentation of supply chain transactions }\end{array}$ & Systems training, monitoring costs \\
\hline 8 & $\begin{array}{l}\text { Achieving a sustainable } \\
\text { municipality }\end{array}$ & $\begin{array}{l}\text { Developing sustainable policies and supplier } \\
\text { contracts, objectives and rating supplier and } \\
\text { partner sustainability }\end{array}$ & $\begin{array}{l}\text { Sustainability performance measurement, } \\
\text { monitoring sustainability of suppliers and } \\
\text { maintaining sustainability contracts }\end{array}$ \\
\hline 9 & $\begin{array}{l}\text { Implementing renewable } \\
\text { resources system }\end{array}$ & $\begin{array}{c}\text { Integrating the system with suppliers, } \\
\text { collaborative sustainability projects with } \\
\text { suppliers, waste management, CO2 footprint } \\
\text { management }\end{array}$ & $\begin{array}{c}\text { Use of renewable raw materials, developing } \\
\text { sustainable supplier policies }\end{array}$ \\
\hline 11 & $\begin{array}{l}\text { Sustainable operations and raw } \\
\text { materials implementation }\end{array}$ & $\begin{array}{l}\text { Ensuring supply of sustainable raw materials, } \\
\text { sustainable operations within the } \\
\text { organization, employee engagement in } \\
\text { sustainability, collaboration with suppliers } \\
\text { and support agencies }\end{array}$ & $\begin{array}{l}\text { Purchasing sustainable raw materials, } \\
\text { establishing sustainability policies for } \\
\text { suppliers and operations, training staff, } \\
\text { calculating NPV of sustainability initiatives }\end{array}$ \\
\hline 12 & Implementation of CSR & $\begin{array}{l}\text { No GMO suppliers, CSR policies for } \\
\text { stakeholders, reducing energy consumption, } \\
\text { policies for ensuring employees' rights }\end{array}$ & $\begin{array}{l}\text { Cost management, staff engagement and } \\
\text { training, recycling resources }\end{array}$ \\
\hline 15 & $\begin{array}{l}\text { Improving the effectiveness of the } \\
\text { sophistication sustainable } \\
\text { purchasing system }\end{array}$ & $\begin{array}{c}\text { Sustainability inventory management and } \\
\text { procurement through ERP, adoption of } \\
\text { international standards for sustainable } \\
\text { inventory management }\end{array}$ & $\begin{array}{c}\text { Improved inventory and procurement data } \\
\text { management and sustainability certification } \\
\text { of suppliers }\end{array}$ \\
\hline 16 & $\begin{array}{l}\text { Supply sustainability and } \\
\text { recycling program } \\
\text { implementation }\end{array}$ & $\begin{array}{c}\text { Selection of sustainable suppliers, waste } \\
\text { management, development of supplier and } \\
\text { implementation of government sustainability } \\
\text { standards }\end{array}$ & $\begin{array}{c}\text { Supplier accreditation and training, selection } \\
\text { of environmentally sustainable raw materials } \\
\text { and services }\end{array}$ \\
\hline
\end{tabular}

\section{References}

1. Lee, H.L.; Tang, C.S. Socially and Environmentally Responsible Value Chain Innovations: New Operations Management Research Opportunities. Manag. Sci. 2017, 64, 983-996. [CrossRef]

2. Reinecke, J.; Donaghey, J. After Rana Plaza: Building coalitional power for labour rights between unions and (consumption-based) social movement organisations. Organization 2015, 22, 720-740. [CrossRef]

3. Walker, H.; Jones, N. Sustainable supply chain management across the UK private sectornull. Supply Chain Manag. Int. J. 2012, 17, 15-28. [CrossRef]

4. Silvestre, B.S. Sustainable supply chain management in emerging economies: Environmental turbulence, institutional voids and sustainability trajectories. Int. J. Prod. Econ. 2015, 167, 156-169. [CrossRef]

5. Jia, F.; Zuluaga-Cardona, L.; Bailey, A.; Rueda, X. Sustainable supply chain management in developing countries: An analysis of the literature. J. Clean. Prod. 2018, 189, 263-278. [CrossRef]

6. Kuutti, K. Activity theory as a potential framework for human-computer interaction research. In Context and Consciousness: Activity Theory and Human-Computer Interaction; Mit Press: Cambridge, MA, USA, 1996; pp. 17-44.

7. Jarzabkowski, P. An activity-theory approach to strategy as practice. In Cambridge Handbook of Strategy as Practice; Cambridge University Press: Cambridge, UK, 2010; pp. 127-140. 
8. Yawar, S.A.; Seuring, S. Management of social issues in supply chains: A literature review exploring social issues, actions and performance outcomes. J. Bus. Ethics 2017, 141, 621-643. [CrossRef]

9. Meixell, M.J.; Luoma, P. Stakeholder pressure in sustainable supply chain management: A systematic review. Int. J. Phys. Distrib. Logist. Manag. 2015, 45, 69-89. [CrossRef]

10. Busse, C. Doing well by doing good? The self-interest of buying firms and sustainable supply chain management. J. Supply Chain Manag. 2016, 52, 28-47. [CrossRef]

11. Dou, Y.; Zhu, Q.; Sarkis, J. Green multi-tier supply chain management: An enabler investigation. J. Purch. Supply Manag. 2017, 24, 95-107. [CrossRef]

12. Gimenez, C.; Tachizawa, E.M. Extending sustainability to suppliers: A systematic literature review. Supply Chain Manag. Int. J. 2012, 17, 531-543. [CrossRef]

13. Zhu, Q.; Sarkis, J.; Lai, K.-H. Institutional-based antecedents and performance outcomes of internal and external green supply chain management practices. J. Purch. Supply Manag. 2013, 19, 106-117. [CrossRef]

14. Zhu, Q.; Sarkis, J.; Lai, K.-H. Confirmation of a measurement model for green supply chain management practices implementation. Int. J. Prod. Econ. 2008, 111, 261-273. [CrossRef]

15. Zhu, Q.; Sarkis, J. Relationships between operational practices and performance among early adopters of green supply chain management practices in Chinese manufacturing enterprises. J. Oper. Manag. 2004, 22, 265-289. [CrossRef]

16. Hajmohammad, S.; Vachon, S.; Klassen, R.D.; Gavronski, I. Reprint of Lean management and supply management: Their role in green practices and performance. J. Clean. Prod. 2013, 56, 86-93. [CrossRef]

17. Cherrafi, A.; Elfezazi, S.; Govindan, K.; Garza-Reyes, J.A.; Benhida, K.; Mokhlis, A. A framework for the integration of Green and Lean Six Sigma for superior sustainability performance. Int. J. Prod. Res. 2017, 55, 4481-4515. [CrossRef]

18. Hassini, E.; Surti, C.; Searcy, C. A literature review and a case study of sustainable supply chains with a focus on metrics. Int. J. Prod. Econ. 2012, 140, 69-82. [CrossRef]

19. Malik, M.; Abdallah, S.; Hussain, M. Assessing supplier environmental performance: Applying analytical hierarchical process in the United Arab Emirates healthcare chain. Renew. Sustain. Energy Rev. 2016, 55, 1313-1321. [CrossRef]

20. Esfahbodi, A.; Zhang, Y.; Watson, G.; Zhang, T. Governance pressures and performance outcomes of sustainable supply chain management-An empirical analysis of UK manufacturing industry. J. Clean. Prod. 2017, 155, 66-78. [CrossRef]

21. Dubey, R.; Gunasekaran, A.; Childe, S.J.; Papadopoulos, T.; Hazen, B.; Giannakis, M.; Roubaud, D. Examining the effect of external pressures and organizational culture on shaping performance measurement systems (PMS) for sustainability benchmarking: Some empirical findings. Int. J. Prod. Econ. 2017, 193, 63-76. [CrossRef]

22. Wilhelm, M.M.; Blome, C.; Bhakoo, V.; Paulraj, A. Sustainability in multi-tier supply chains: Understanding the double agency role of the first-tier supplier. J. Oper. Manag. 2016, 41, 42-60. [CrossRef]

23. Foerstl, K.; Azadegan, A.; Leppelt, T.; Hartmann, E. Drivers of supplier sustainability: Moving beyond compliance to commitment. J. Supply Chain Manag. 2015, 51, 67-92. [CrossRef]

24. Wong, C.Y.; Wong, C.W.; Boon-Itt, S. Integrating environmental management into supply chains: A systematic literature review and theoretical framework. Int. J. Phys. Distrib. Logist. Manag. 2015, 45, 43-68. [CrossRef]

25. Andersen, M.; Skjoett-Larsen, T. Corporate social responsibility in global supply chains. Supply Chain Manag. Int. J. 2009, 14, 75-86. [CrossRef]

26. Teuscher, P.; Grüninger, B.; Ferdinand, N. Risk management in sustainable supply chain management (SSCM): Lessons learnt from the case of GMO-free soybeans. Corp. Soc. Responsib. Environ. Environ. Manag. 2006, 13, 1-10. [CrossRef]

27. Linton, J.D.; Klassen, R.; Jayaraman, V. Sustainable supply chains: An introduction. J. Oper. Manag. 2007, 25, 1075-1082. [CrossRef]

28. Appolloni, A.; Sun, H.; Jia, F.; Li, X. Green Procurement in the private sector: A state of the art review between 1996 and 2013. J. Clean. Prod. 2014, 85, 122-133. [CrossRef]

29. Govindan, K.; Kannan, D.; Shankar, M. Evaluation of green manufacturing practices using a hybrid MCDM model combining DANP with PROMETHEE. Int. J. Prod. Res. 2015, 53, 6344-6371. [CrossRef]

30. Gualandris, J.; Kalchschmidt, M. Developing environmental and social performance: The role of suppliers' sustainability and buyer-supplier trust. Int. J. Prod. Res. 2016, 54, 2470-2486. [CrossRef] 
31. Song, M.; Zheng, W.; Wang, Z. Environmental efficiency and energy consumption of highway transportation systems in China. Int. J. Prod. Econ. 2016, 181, 441-449. [CrossRef]

32. Nikolaou, I.E.; Evangelinos, K.I.; Allan, S. A reverse logistics social responsibility evaluation framework based on the triple bottom line approach. J. Clean. Prod. 2013, 56, 173-184. [CrossRef]

33. Beske, P. Dynamic capabilities and sustainable supply chain management. Int. J. Phys. Distrib. Logist. Manag. 2012, 42, 372-387. [CrossRef]

34. El Baz, J.; Laguir, I. Third party logistics providers (TPLs) and environmental sustainability practices in developing countries: The case of Morocco. Int. J. Oper. Prod. Manag. 2017, 37, 1451-1474. [CrossRef]

35. Govindan, K.; Jha, P.; Garg, K. Product recovery optimization in closed-loop supply chain to improve sustainability in manufacturing. Int. J. Prod. Res. 2016, 54, 1463-1486. [CrossRef]

36. Ciliberti, F.; Pontrandolfo, P.; Scozzi, B. Logistics social responsibility: Standard adoption and practices in Italian companies. Int. J. Prod. Econ. 2008, 113, 88-106. [CrossRef]

37. Del Borghi, A.; Gallo, M.; Strazza, C.; Del Borghi, M. An evaluation of environmental sustainability in the food industry through Life Cycle Assessment: The case study of tomato products supply chain. J. Clean. Prod. 2014, 78, 121-130. [CrossRef]

38. Babu, S.; Mohan, U. An integrated approach to evaluating sustainability in supply chains using evolutionary game theory. Comput. Oper. Res. 2018, 89, 269-283. [CrossRef]

39. Koh, S.C.L.; Angappa, G.; Jonathan, M.; Raymond, O.; Mohammad, E.S. Conceptualising a circular framework of supply chain resource sustainability. Int. J. Oper. Prod. Manag. 2017, 37, 1520-1540. [CrossRef]

40. Hutchins, M.J.; Sutherland, J.W. An exploration of measures of social sustainability and their application to supply chain decisions. J. Clean. Prod. 2008, 16, 1688-1698. [CrossRef]

41. Becker, W.S.; Carbo, J.A.; Langella, I.M. Beyond self-interest: Integrating social responsibility and supply chain management with human resource development. Hum. Resour. Dev. Rev. 2010, 9, 144-168. [CrossRef]

42. Kennedy, M.; Basu, B. Overcoming barriers to low carbon technology transfer and deployment: An exploration of the impact of projects in developing and emerging economies. Renew. Sustain. Energy Rev. 2013, 26, 685-693. [CrossRef]

43. Gold, S.; Seuring, S.; Beske, P. Sustainable supply chain management and inter-organizational resources: A literature review. Corp. Soc. Responsib. Environ. Manag. 2010, 17, 230-245. [CrossRef]

44. Hansen, U.E.; Ockwell, D. Learning and technological capability building in emerging economies: The case of the biomass power equipment industry in Malaysia. Technovation 2014, 34, 617-630. [CrossRef]

45. Awaysheh, A.; Klassen, R.D. The impact of supply chain structure on the use of supplier socially responsible practices. Int. J. Oper. Prod. Manag. 2010, 30, 1246. [CrossRef]

46. Jayakumar, T. From philanthropy to strategic corporate sustainability: A case study in India. J. Bus. Strategy 2016, 37, 39-50. [CrossRef]

47. Hsu, C.-C.; Tan, K.-C.; Zailani, S.H.M. Strategic orientations, sustainable supply chain initiatives, and reverse logistics: Empirical evidence from an emerging market. Int. J. Oper. Prod. Manag. 2016, 36, 86-110. [CrossRef]

48. Kusi-Sarpong, S.; Sarkis, J.; Wang, X. Assessing green supply chain practices in the Ghanaian mining industry: A framework and evaluation. Int. J. Prod. Econo. 2016, 181, 325-341. [CrossRef]

49. Manning, S.; Boons, F.; von Hagen, O.; Reinecke, J. National contexts matter: The co-evolution of sustainability standards in global value chains. Ecol. Econ. 2012, 83, 197-209. [CrossRef]

50. Jarzabkowski, P. Strategic practices: An activity theory perspective on continuity and change. J. Manag. Stud. 2003, 40, 23-55. [CrossRef]

51. Lin, F.-R.; Hsieh, P.-S. Analyzing the sustainability of a newly developed service: An activity theory perspective. Technovation 2014, 34, 113-125. [CrossRef]

52. Ellington, V.B. Application of Activity Modeling to a 'Dirt to Shirt' Supply Chain. IUP J. Supply Chain Manag. 2017, 14, 24-37.

53. Johnson, G.; Langley, A.; Melin, L.; Whittington, R. Practical Theories. In Strategy as Practice: Research Directions and Resources; Cambridge University Press: New York, NY, USA, 2007; pp. 30-49.

54. Leont'ev, A.N. Activity, Consciousness, and Personality; Prentice-Hall: Upper Saddle River, NJ, USA, 1978.

55. Esfahbodi, A.; Zhang, Y.; Watson, G. Sustainable supply chain management in emerging economies: Trade-offs between environmental and cost performance. Int. J. Prod. Econ. 2016, 181, 350-366. [CrossRef]

56. Zailani, S.; Jeyaraman, K.; Vengadasan, G.; Premkumar, R. Sustainable Supply Chain Management (SSCM) in Malaysia: A Survey. Int. J. Prod. Econ. 2012, 140, 330-340. [CrossRef] 
57. Sharp, Z.; Zaidman, N. Strategization of CSR. J. Bus. Ethics 2010, 93, 51-71. [CrossRef]

58. Blackler, F.; Regan, S. Intentionality, agency, change: Practice theory and management. Manag. Learn. 2009, 40, 161-176. [CrossRef]

59. Pispa, J.; Eriksson, I.V. Aligning organizations and their information technology infrastructure: How to make information technology support business. Prod. Plan. Control 2003, 14, 193-200. [CrossRef]

60. Greig, G.; Entwistle, V.A.; Beech, N. Addressing complex healthcare problems in diverse settings: Insights from activity theory. Soc. Sci. Med. 2012, 74, 305-312. [CrossRef]

61. CIA. The World Fact Book: People and Society: United Arab Emirates. Available online: https://www.cia. gov/library/publications/the-world-factbook/geos/ae.html (accessed on 18 March 2018).

62. Sarkis, J.; Helms, M.M.; Hervani, A.A. Reverse logistics and social sustainability. Corp. Soc. Responsib. Environ. Manag. 2010, 17, 337-354. [CrossRef]

63. Yin, R.K. Validity and generalization in future case study evaluations. Evaluation 2013, 19, 321-332. [CrossRef]

64. Fereday, J.; Muir-Cochrane, E. Demonstrating rigor using thematic analysis: A hybrid approach of inductive and deductive coding and theme development. Int. J. Qual. Methods 2006, 5, 80-92. [CrossRef]

65. Vieira, L.C.; Amaral, F.G. Barriers and strategies applying Cleaner Production: A systematic review. J. Clean. Prod. 2016, 113, 5-16. [CrossRef]

66. Jayanti, R.K.; Gowda, M.V.R. Sustainability dilemmas in emerging economies. IIMB Manag. Rev. 2014, 26, 130-142. [CrossRef]

67. Shi, H.; Peng, S.Z.; Liu, Y.; Zhong, P. Barriers to the implementation of cleaner production in Chinese SMEs: Government, industry and expert stakeholders' perspectives. J. Clean. Prod. 2008, 16, 842-852. [CrossRef]

68. Thorpe, J.; Prakash-Mani, K. Developing value: The business case for sustainability in emerging markets. Greener Manag. Int. 2003, 44, 17-32. [CrossRef]

69. Bebbington, J.; Larrinaga, C. Accounting and sustainable development: An exploration. Account. Organ. Soc. 2014, 39, 395-413. [CrossRef]

70. Ramanathan, R. Supplier selection problem: Integrating DEA with the approaches of total cost of ownership and AHP. Supply Chain Manag. Int. J. 2007, 12, 258-261. [CrossRef]

71. Fraser, M. "Fleshing out" an engagement with a social accounting technology. Account. Audit. Account. J. 2012, 25, 508-534. [CrossRef]

72. Krause, D.R.; Vachon, S.; Klassen, R.D. Special topic forum on sustainable supply chain management: Introduction and reflections on the role of purchasing management. J. Supply Chain Manag. 2009, 45, 18-25. [CrossRef]

73. Gombault, M.; Versteege, S. Cleaner production in SMEs through a partnership with (local) authorities: Successes from the Netherlands. J. Clean. Prod. 1999, 7, 249-261. [CrossRef]

74. Sroufe, R.; Liebowitz, J.; Sivasubramaniam, N. Are you a leader or a laggard? HR's role in creating a sustainability culture. People Strategy 2010, 33, 34.

75. Henriques, I.; Sadorsky, P. The relationship between environmental commitment and managerial perceptions of stakeholder importance. Acad. Manag. J. 1999, 42, 87-99.

(C) 2019 by the authors. Licensee MDPI, Basel, Switzerland. This article is an open access article distributed under the terms and conditions of the Creative Commons Attribution (CC BY) license (http://creativecommons.org/licenses/by/4.0/). 